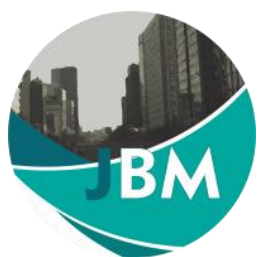

\title{
Peran Pengusaha Perempuan UMKM dan Pola Pengeluaran Rumah Tangga pada Situasi Bencana Covid-19
}

Submitted Date:

4 Maret 2021

Accepted Date:

6 Mei 2021
Susy Yunia Rahmawijaya Sanie

Universitas Katolik Atma Jaya- Jakarta susy.sanie@atmajaya.ac.id

Benedicta Eviena Prabawati

Universitas Katolik Atma Jaya- Jakarta benedicta.ep@atmajaya.ac.id

\section{Suggested Citation :}

Stawicki, Stanislawp, and et al. (2020). "The 2019-2020 novel coronavirus (Severe acute respiratory syndrome coronavirus 2) pandemic: A joint american college of academic international medicine-world academic council of emergency medicine multidisciplinary COVID-19 working group consensus paper." Journal of Global Infectious Diseases 12 (2): 47-93. doi:10.4103/jgid.jgid_86_20.

\section{Abstact:}

This descriptive research using a qualitative approach photographing the adjustment of the activities of women entrepreneurs in aim to describe women's behavior in terms of their role as working women who own independent micro/small businesses, as well as wives and mothers for their children in the COVID-19 disaster situation in Indonesia. This research is expected to help women MSME entrepreneurs as the main decision makers in the household, especially those related to economic decisions and decisions related to maintaining family health. Research findings illustrate that the domestic role of women entrepreneurs is increasing in the situation of the Covid disaster, especially in the care and education of children, in addition to cooking/providing nutritious food and vitamins. The situation also had an impact on adjusting the economic role of women entrepreneurs in public, including doing work from home, losing jobs, and losing customers. In order to survive, it is necessary to make adjustments to more economical household expenditure patterns, aside from developing new household goods/services businesses for additional income. Savings were also made, in order to stay afloat with the current income. Another finding related to the social role of women entrepreneurs in the situation of the Covid disaster is that they set aside the money proceeds from their efforts to continue to do good deeds/share with their families, neighbors, or other community members in need.

Keywords: covid-19 disaster, household expenditure patterns, the role of women, women entrepreneurs,

Abstrak:

Penelitian deskriptif ini menggunakan pendekatan kualitatif yang memotret penyesuaian aktivitas perempuan pengusaha, bertujuan mendeskripsikan perilaku perempuan ditinjau dari perannya sebagai perempuan bekerja yang memiliki usaha mikro/kecil mandiri, serta sebagai istri dan ibu bagi anaknya pada situasi bencana COVID-19 di Indonesia. Penelitian ini diharapkan dapat membantu para pengusaha UMKM perempuan sebagai pengambil keputusan utama dalam rumah tangga, khususnya yang berkaitan dengan keputusan ekonomi dan keputusan terkait dengan menjaga kesehatan keluarga. Temuan penelitian menggambarkan peran domestik perempuan pengusaha semakin meningkat dalam situasi bencana Covid ini, khususnya dalam pengasuhan dan pendidikan anak, selain memasak/menyediakan makanan bergizi dan vitamin. Situasi bencana Covid ini juga berdampak adanya penyesuaian peran ekonomi perempuan pengusaha di masyarakat, diantaranya: melakukan pekerjaan dari rumah, kehilangan pekerjaan, serta kehilangan pelanggan. Supaya bertahan, perlu dilakukan penyesuaian pola pengeluaran rumah tangga yang lebih ekonomis, selain mengembangkan usaha baru barang/jasa rumah tangga untuk tambahan penghasilan. Penghematan juga dilakukan, untuk tetap dapat bertahan dengan pendapatan yang ada saat ini. Temuan lain terkait peran sosial pengusaha perempuan di dalam situasi bencana Covid ini adalah mereka menyisihkan hasil dari usahanya untuk tetap beramal/berbagi kepada keluarga, tetangga, atau warga masyarakat lain yang membutuhkan.

Kata Kunci: bencana Covid-19, peran perempuan, pengusaha perempuan, pola pengeluaran rumah tangga

JEL Classification : R11 


\section{Latar Belakang}

Perempuan merupakan kelompok masyarakat yang rentan dan paling merasakan dampak dari bencana yang terjadi. Jadi, selain karena jumlah penduduk perempuan yang hampir separuh $(49,42 \%)$ dari total jumlah penduduk di Indonesia (BPS -a 2021), perempuan sebagai anggota masyarakat yang rentan mengalami dampak buruk bencana, merupakan aspek penting yang sudah semestinya mendapat perhatian pada saat terjadi dan dilibatkan partisipasinya dalam perencanaan atau penyusunan strategi saat menghadapi bencana, termasuk bencana pandemi Covid-19 yang sedang terjadi.

Urgensi penelitian ini adalah sebagai penelitian kerat-lintang (cross-sectional) yang mengobservasi dan memotret data pada situasi Pandemi COVID-19 yang sedang terjadi. Padahal pandemi merupakan peristiwa langka. Tercatat dalam sejarah manusia hanya ada 20 pandemi yang pernah terjadi (Rosenwald, 2020). Pandemi dalam kurun waktu 100 tahun sepanjang abad 20 relatif lebih sering, dimana ada 4 pandemi termasuk Covid-19 ini (Roychoudhury, et al., 2020). Selain itu penelitian ini memotret apa yang telah dan bisa dilakukan perempuan sebagai pelaku usaha UMKM dalam perannya sebagai pengambil keputusan utama di dalam bisnis yang dijalankan serta di dalam rumah tangganya untuk mencegah penularan, melindungi dan merawat anggota rumah tangganya, dan juga penyesuaian yang dilakukan oleh pengusaha perempuan dalam mengelola ekonomi rumah tangga.dan juga dalam pengelolaan usaha supaya tetap berjalan meskipun berada pada situasi dilanda bencana seperti yang terjadi saat ini.

Berkaitan dengan perempuan dan peran strategis nya dalam situasi bencana. Data penduduk berdasarkan Sensus Penduduk September 2020 oleh Badan Pusat Statistik (BPS), menyatakan jumlah penduduk Indonesia sebesar 270,20 juta jiwa. Menurut jenis kelamin, jumlah tersebut terdiri atas 136,66 juta jiwa laki-laki dan 133,54 juta jiwa perempuan (BPS -a 2021). Pada periode waktu saat ini dapat dikatakan bahwa Indonesia sedang menikmati masa bonus demografi dimana jumlah penduduk usia produktif lebih banyak dari usia tidak produktif. Penduduk usia produktif penduduk yaitu kelompok umur 15-64 tahun sebanyak 189,64 juta jiwa atau sebesar $70,72 \%$ dari total populasi. Sisanya penduduk usia non-produktif, terdiri dari katagori bayi s/d usia sekolah (0-14 tahun) sebanyak 23,33\% dan lansia (usia 65 tahun ke atas) sebanyak 5,95\% (BPS -b 2021). Perempuan sebagai sumberdaya manusia Indonesia yang jumlahnya hampir separuh $(49,42 \%)$ dari total populasi dan mayoritas berada dalam usia produktif, selayaknyalah dimanfaatkan untuk mencapai tujuan negara adil dan makmur. Saat ini, partisipasi perempuan Indonesia dalam pembangunan di semua bidang dan perannya dalam kehidupan berbangsa-bernegara cukup signifikan. Termasuk peran dan partisipasi perempuan dalam menanggulangi bencana.

Definisi bencana dapat berbeda-beda karena dibuat untuk kepentingan legalitas upaya yang akan dilakukan oleh lembaga yang mendefenisikannya, yaitu: pemerintah (Presiden Republik Indonesia 2007), atau lembaga-lembaga internasional yang terkait seperti ISDR (International Strategy for Disaster Reduction (ISDR) 2009); dan Organisasi Kesehatan Dunia (WHO/EHA 2002). Namun, definisi mengenai "bencana" biasanya merefleksikan karakteristik yang serupa tentang: gangguan yang terjadi pada pola hidup manusia; akibat bencana yang terjadi bagi manusia dan/atau bagi struktur sosial; dampak yang terjadi pada kerusakan aspek sistem pemerintahan, pada bangunan, dan lain-lain (Nugroho 2016).

Wujud bencana ada berbagai bentuk yang dapat dikatagorikan sebagai: bencana alam (terdiri dari bencana geologi (gempa, letusan gunung berapi, longsor, lifakuasi, dII), dan bencana hidrometerologi seperti banjir, rob, tsunami, badai/angin topan, kekeringan); bencana teknologi (kecelakaan/kegagalan industri, kecelakaan transportasi, kesalahan desain teknologi, dan kelalaian manusia dalam pengoperasian produk teknologi); bencana lingkungan (pencemaran, abrasi pantai, kebakaran (urban fire), dan kebakaran hutan); bencana sosial-ekonomi (konflik sosial, terorisme/ledakan bom, dan eksodus (pengungsian/berpindah tempat secara besar-besaran), krisis moneter); dan bencana biologis yaitu epidemi dan penyakit tanaman/hewan (Nurjanah 2012), termasuk bencana yang terjadi saat ini yaitu pandemi COVID-19. Apapun bentuknya, bencana selalu berakibat pada perubahan tatanan kehidupan di masyarakat, dan berdampak pada terjadinya perubahan kebutuhan masyarakat.

Pemberdayaan masyarakat yang terancam bencana merupakan kunci keberhasilan upaya mitigasi dampak bencana dalam bentuk dan pada jenis bencana apapun. Selain itu, proses perencanaan yang partisipatif merupakan prasyarat agar upaya mitigasi dapat berkelanjutan, selain agar tindakan penanganan yang dilakukan tepat sasaran dan sesuai dengan kebutuhan masyarakat yang terdampak serta pemangku kepentingan lainnya (Rahman, 2018).

Peran strategis perempuan dalam menghadapi bencana dapat menekan resiko yang ditimbulkan akibat bencana. Sehingga perlu upaya meningkatkan peran perempuan dalam mitigasi bencana. Untuk meningkatkan 
kemampuan perempuan dalam mengurangi risiko bencana dapat dilakukan melalui peningkatan: 1. Kesadaran perempuan dalam memahami situasi lingkungan dan ancaman bahaya 2. Pemahaman tentang kerentanan dan kemampuan untuk mengukur kapasitas yang dimiliki perempuan 3. Kemampuan untuk menilai risiko yang dihadapi perempuan sebagai individu, anggota keluarga dan anggota masyarakat. 4. Kemampuan untuk merencanakan dan melakukan tindakan untuk mengurangi risiko yang dimiliki baik melalui peningkatan kapasitas dan mengurangi kerentanan. 5. Kemampuan perempuan untuk memantau, mengevaluasi dan menjamin keberlangsungan upaya pengurangan risiko sehingga dampak bencana dapat dikurangi atau dicegah (Hastuti, 2016). Berdasarkan pada kondisi tersebut maka melakukan upaya peningkatan peranserta perempuan dalam menghadapi bencana menjadi variabel penting yang dapat dilakukan untuk menekan lebih banyak kerugian/dampak sosial-ekonomi bahkan kehilangan jiwa yang terjadi akibat bencana, termasuk pada bencana COVID-19 ini.

Pemberian informasi yang jelas secara transparan dan terbuka tentang resiko bencana COVID-19 di dalam kehidupan sehari-hari merupakan langkah yang diharapkan mampu mengurangi resiko tertular lebih cepat dari virus COVID-19 ini. Perempuan tidak hanya perlu dikenalkan dengan lingkungan tempat tinggal mereka agar mampu memahami dinamika alam yang ada di sekitar tempat tinggal mereka, tetapi perempuan juga diberikan pengetahuan tentang resiko yang akan muncul bila terjadi bencana. Dalam situasi pandemi Covid-19, berarti perlu edukasi tentang risiko yang akan dialami jika ada anggota keluarga, tetangga terdekat di daerah tempat tinggal mereka sampai ada yang tertular virus COVID-19 ini. Dengan demikian, perempuan menjadi kelompok masyarakat yang dapat dilibatkan dalam mengurangi jumlah manusia yang terpapar dan korban yang meninggal akibat pandemi Covid-19.

Bencana pandemi covid-19 berdampak pada perekonomian di Indonesia. Pada 11 Maret 2020 organisasi kesehatan dunia (WHO) telah menetapkan COVID-19 sebagai pandemic (Sebayang, 2020). Kondisi yang ada saat ini tidak boleh dianggap remeh, karena hanya ada beberapa penyakit saja sepanjang sejarah yang pernah ada yang tergolong sebagai pandemi. Pandemi, adalah sebuah epidemi yang menyebar ke beberapa negara atau benua, dan pada umumnya menjangkiti banyak orang. Epidemi merupakan istilah yang sudah sering digunakan terkait peningkatan jumlah kasus penyakit secara tiba-tiba pada suatu populasi di area tertentu. Istilah pandemi tidak digunakan untuk menunjukkan tingkat keparahan suatu penyakit, melainkan hanya menunjukkan tingkat penyebarannya saja. Sampai 29 April 2021 Covid-19 sudah menyebar ke 222 negara, menjangkiti 150,810,078 orang, dimana ada 3,171,207 orang meninggal, 18,860,688 orang masih dirawat, dan 128,778,183 orang telah sembuh (Worldometer 2021).

Setiap kejadian pandemi selalu berdampak buruk bagi perekonomian (GHRF Commission (Commission on a Global Health Risk Framework for the Future), 2016) yang sebelumnya seringkali luput dari antisipasi kebijakan maupun diskusi ilmiah. Wold Bank (2019) telah memprediksi besaran \$13 Milyar untuk mengantisipasi dampak bencana. Bencana pandemi COVID-19 ini berdampak pada memburuknya situasi perekonomian global (Stawicki, et. al., 2020), dimana angka PDB mengalami pertumbuhan negative, dan pengangguran meningkat. Hal ini juga terjadi di Indonesia. Pemerintah RI telah mengeluarkan kebijakan fiskal extraordinary untuk penanganan Covid-19 dan mitigasi dampak ekonomi berupa dana stimulus dalam 3 tahap yang secara total senilai Rp.435,1 Triliyun, ditambah Rp 245 Triliyun yang bersumber dari dana penghematan dan relokasi anggaran kementrian/lembaga pemerintah pusat dan pemda th 2020 yang difokuskan untuk penanggulangan bencana Covid-19 (Kementerian Keuangan Republik Indonesia 2020). Angka PDB Indonesia pada akhir 2020 adalah Rp.3.929,2 Triliyun, yang berarti pertumbuhan ekonomi Indonesia terkontraksi sebesar -2,7\% dibandingkan akhir 2019 sebelum bencana pandemi Covid-19 melanda negeri ini (BPS -c 2021).

Setahun bencana pandemic Covid-19 telah membuat angka pengangguran terbuka (TPT) meningkat 1,84\% menjadi 7,07 \% , sehingga jumlah pengangguran mencapai 138,22 juta orang. Dampak setahun Covid-19 terhadap pekerja di Indonesia adalah: sejumlah 9,46 juta orang yang kehilangan/tidak lagi bekerja penuhwaktu (full timer), sedangkan pekerja paruh waktu bertambah 4,32 juta orang, dan orang yang setengah menganggur bertambah sebanyak 4,83 juta orang. Tambahan pertanyaan dalam kuesioner Sakernas - Agustus 2020, memberikan data yang lebih rinci, yaitu: ada sebanyak 29,12 juta penduduk usia kerja (14,28 persen) terdampak Covid-19 pada Agustus 2020, dengan rincian: 2,56 juta penduduk menjadi pengangguran, 0,76 juta penduduk menjadi bukan angkatan kerja (yaitu: penduduk usia kerja (15 tahun dan lebih) yang masih sekolah, mengurus rumah tangga atau melaksanakan kegiatan lainnya selain kegiatan pribadi), 1,77 juta penduduk sementara tidak bekerja (statusnya masih punya pekerjaan, tetapi tidak bekerja/tidak ada kerjaan dalam kurun waktu minimal seminggu yang lalu), 24,03 juta penduduk bekerja dengan pengurangan jam kerja (shorter hours). Yang menarik, 
Angka Tingkat Partisipasi Angkatan Kerja (TPAK) justru meningkat sedikit $(0,24 \%)$ menjadi $67,77 \%$ hal ini dikarenakan meskipun TPAK laki-laki menurun $0,84 \%$ menjadi $82,41 \%$, angkaTPAK perempuan justru meningkat $1,32 \%$ menjadi $53,13 \%$ (BPS-d 2020). Hal ini berarti cukup banyak perempuan yang terdorong bekerja mencari nafkah tambahan pada masa Covid ini, meski kemungkinan besar hanya jadi pekerja paruh waktu atau setengah menganggur. Dapat diduga, salah satu faktor yang mendorong perempuan 'keluar' dari peran domestik yang bersifat produktif tak langsung, dan menjalankan peran ekonomi publik yang produktif langsung karena memberi penghasilan dalam bentuk uang, adalah adanya tekanan ekonomi di level individu/rumah tangga; disamping adanya kesempatan/peluang dan waktu luang diakibatkan penerapan protocol kesehatan mencegah penularan Covid-19 yang mengharuskan bekerja/belajar dari rumah. Dugaan ini didukung fakta bahwa pendapatan per kapita yang menurun dan tingkat kemiskinan yang meningkat selama bencana Covid 19 ini.

Banyaknya penduduk usia kerja terpuruk akibat Covid-19 yang mencapai hampr tigapuluh juta orang, jelas membuat tingkat pendapatan menurun. Penurunan pendapatan berdasarkan PDB per kapita pada 2020 sebesar Rp2,2 juta dari sebelum pandemi Covid-19 (Lokadata 2021) menjadi Rp56,9 juta setara US\$ 3.911,7 (BPS -c 2021). Penurunan pendapatan per kapita ini, secara logis membuat tingkat kemiskinan meningkat.

Tingkat kemiskinan pada September 2020 adalah 10,19\% sehingga ada 27,55 juta orang penduduk miskin di Indonesia. Dibandingkan dengan data pada awal terjadinya Covid-19 pada Maret 2020, ada kenaikan tingkat kemiskinan sebesar $0,41 \%$, yang berarti ada pertambahan 1,13 juta orang miskin selama bencana Covid19 berlangsung (BPS -e 2021). Secara garegat, data nasional menunjukkan pengeluaran konsumsi rumah tangga pada triwulan III 2020 terkontraksi sebesar 4,05 persen, menurun dibandingkan periode yang sama tahun 2019 yang tumbuh sebesar 5,01 persen (BPS -e 2021). Pada level individu rumah tangga konsumen, situasi ini menuntut perempuan sebagai pengambilan keputusan ekonomi keluarga harus lebih bijak dalam mengelola keuangan rumah tangganya agar dapat bertahan hidup (survive).

Pemahaman perempuan dalam perannya sebagai Ibu terhadap wabah COVID-19 yang meliputi cara penularan, risiko terhadap kesehatan dan keselamatan manusia, cara pencegahan, dan penanganan bila ada yang terpapar oleh virus COVID-19, menjadi prasyarat utama untuk melakukan berbagai upaya dalam memerangi virus COVID-19 dan melindungi keluarga dan seluruh anggota rumah tangganya, bahkan juga tetangga sekitarnya. Selain itu situasi ekonomi yang terpuruk akibat wabah menuntut perempuan sebagai pengambil keputusan keuangan rumah tangga harus mampu bertindak bijak dalam mengelola keuangan rumah tangga agar bisa bertahan pada saat bencana COVID-19 ini. Berdasarkan uraian di atas maka penelitian ini akan menganalisis peran perempuan sebagai ibu dan pencari nafkah baik sebagai pekerja maupun pemilik usaha UMKM dalam menyikapi bencana COVID-19 di Indonesia. Menurut Hubeis (2010), analisis terhadap peran perempuan dapat dilakukan dari perspektif posisi dan aktifitas mereka dalam berurusan dengan pekerjaan produktif tidak langsung (domestik) dan pekerjaan produktif langsung (publik). Berdasarkan keseimbangan kedua katagori aktifitas pekerjaan tersebut dalam peran perempuan secara individual, maka aplikasi peran perempuan di masyarakat dari masa ke masa dapat dikelompokkan menjadi 5 katagori: tradisi, transisi, dwiperan, egalitarian, dan kontemporer.

Penelitian ini bertujuan mendeskripsikan perilaku perempuan dalam kerangka perannya sebagai ibu yang bekerja pemilik usaha UMKM dan sebagai istri serta ibu bagi anak-anaknya pada saat situasi bencana COVID19 di Indonesia; sebagai pengambil keputusan utama dalam rumah tangga, khususnya terkait dalam keputusan ekonomi dan keputusan yang berhubungan dengan menjaga kesehatan keluarga.

\section{Metode Penelitian}

Penelitian ini merupakan penelitian deskriptif yang memotret perilaku perempuan dalam menjalankan perannya sebagai ibu yang bekerja ataupun menjadi pengusaha UMKM dalam situasi bencana Pandemi Covid-19 saat ini. Pengumpulan data menggunakan pendekatan kualitatif dengan metoda wawancara mendalam (IDI = In-Depth Interview). Pemilihan informan kunci (key informant) yang menjadi narasumber dilakukan berdasarkan kriteria tertentu. Kriteria untuk menjadi informan kunci (key informant) dalam penelitian ini adalah perempuan yang bekerja dan/atau pemilik usaha mikro dan kecil (UMKM) yang sudah menikah, sehingga memiliki kesempatan penuh untuk menjalankan peran ganda sebagi ibu rumah tangga dan sebagai pengusaha/pekerja mandiri atau karyawan. Selain itu, pendapatan rumah tangga perempuan yang menjadi inform kunci penelitian mengalami penurunan selama bencana pandemi Covid-19.

Data yang dikumpulkan meliputi: 2 variabel yaitu: bencana pandemi Covid 19 dan peran perempuan selama pandemi Covid-19. Variabel Bencana pandemi Covid-19 terdiri dari 4 dimensi, yaitu: persepsi dan sikap terhadap bencana Covid-19, pengetahuan dan perilaku tentang cara pencegahan Covid-19 yang harus dilakukan 


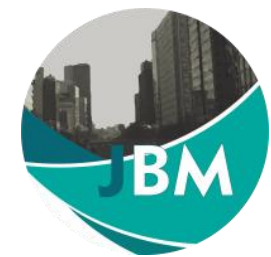

di rumah. Sedangkan variabel peran perempuan dibagi 2 mengikuti konsep Hubeis (Hubeis 2010), yaitu: kegiatan-kegiatan dalam pekerjaan peran produktif tak langsung dan peran produktif langsung. Peran produktif tak langsung yang digali informasinya meliputi: kegiatan sehari-hari sebagai ibu rumah tangga, kegiatan dalam peran sebagai pengelola keuangan rumah tangga, dan kegiatan-kegiatan dalam melaksanakan peran sosial sebagai anggota masyarakat. Sedangkan peran produktif langsung meliputi peran ekonomi dalam menambah penghasilan rumah tangga termasuk mengelola usaha yang dimiliki.

\section{Hasil Penelitian \& Pembahasan}

\section{Persepsi, Sikap, Pengetahuan dan Praktek (Perilaku) terhadap Bencana Covid-19.}

Sesuai dengan teori tentang bencana, kesadaran akan eksistensi bencana merupakan motivasi awal untuk melakukan langkah-langkah yang tepat dalam mengantisipasi bencana. Mengakui adanya bencana mendorong orang untuk bertindak cepat untuk menghindari resiko bahaya yang ditimbulkan. Para informan semuanya menyadari dan mengakui bahwa serangan penyakit Covid-19 merupakan bencana, namun dengan argument yang berbeda. Ada yang menganggapnya bencana karena luasnya penyebaran penyakit Covid-19 yang sampai ke banyak negara sehingga disebut pandemi. Argument lain yang menjadikan serangan penyakit Covid-19 merupakan bencana, adalah bahaya dari penyakit tersebut yang menyebar cepat dan menimbulkan kematian. Yang cukup menarik, Covid-19 dianggap bencana oleh informan bukan saja dari sisi dampaknya terhadap kesehatan, tetapi juga karena berimbas pada lumpuhnya perekonomian.

"....Covid (adalah) bencana... Tiba-tiba aja (datangnya)... cepet, tau-tau banyak yang kena sakit, dan banyak juga yang mati..."(pr, 36 th, SMA, ex-pegawai Salon, usaha jasa pijat/lulur)

“....Bencana. Usaha pada tutup...banyak yang jadi ga kerja, 'dirumahkan'; di PHK... bener-bener bencana deh..."(pr, 48 th, S1, ex-kabag HRD di perusahaan travel, usaha roti rumahan)

Para informan mengaku takut dan khawatir dengan situasi bencana Covid-19 ini karena penyakit ini tidak kenal batas antara si kaya dan miskin, juga batas wilayah, bahkan negara adidaya di dunia secara global juga mengalami banyak kasus penularan dan kasus kematian.

“....Bencana...mengkhawatirkan ya... sebab penularannya cepat dan meluas, bahkan negara-negara kaya di dunia pun kena..." (pr, 44 th, S2, dosen swasta, usaha jual beli emas)

Sikap yang mereka ambil adalah mewaspadai serangan penyakit Covid-19 agar diri dan keluarga tidak sampai tertular, dengan cara mengikuti informasi apapun tentang Covid-19 dan menjalankan upaya-upaya yang diperlukan berdasarkan informasi yang mereka terima. Upaya pencegahan yang dilakukan adalah menerapkan protokol kesehatan bagi anggota keluarga di rumah. Seperti sering mencuci tangan dan memastikan cara mencuci tangan dengan benar, memakai masker bila keluar rumah, menjaga jarak dan menghindari bersentuhan dengan orang lain. Selain itu informan mengatakan sedapat mungkin menghindari berpergian, khususnya tempat yang ada banyak orang berkerumun.

".... Saya kalau belanja, suka lihat-lihat dulu... kalau rame saya ga mau masuk, lebih baik pergi cari tempat lain..." (pr, 40 th, S1, karyawan swasta, WFH, usaha kue rumahan)

".... Pernah saya lagi mau beli sesuatu..., terus lihat antrian nya berjubel. Ga jadi deh..., medingan pulang saya...biar besok-besok aja dah belinya, kalau pas sepi... pas bukan hari Minggu gitu..." (pr, 36 th, SMA, pegawai Salon, usaha jasa pijat/lulur panggilan)

Kalaupun terpaksa keluar rumah, misalnya suami atau mereka sendiri harus bekerja, sedapat mungkin memakai pakaian tertutup. Dan ketika pulang segera mandi keramas dan merendam pakaian yang dikenakan dengan deterjen, sebelum menyapa anak-anak atau orangtua dan anggota keluarga lainnya yang ada di rumah. Cukup menarik bahwa para informan juga menyebutkan upaya pencegahan lainnya, yaitu: menjaga imunitas tubuh mereka sendiri dan anggota keluarga. Hal yang paling banyak disebutkan adalah mengatur asupan makanan anggota keluarga dengan menyediakan makanan yang lebih bergizi, serta memastikan semua anggota keluarga minum vitamin, terutama vitamin $\mathrm{C}$, minum ramuan herbal atau jamu-jamuan, madu, dan lain-lain sejenisnya yang dapat meningkatkan daya tahan tubuh. Kebanyakan informasi tentang bahan-bahan makanan atau minuman serta apa yang disebut salah seorang informan dengan istilah "obat penangkal Covid" diperoleh dari 
media sosial, meskipun ada yang menyatakan dapat dari anjuran teman sekerja atau saudara/keluarga besar bahkan dari kenalan atau saudara yang jadi dokter.

\section{Peran Domestik Perempuan: Kegiatan Produktif Tak Langsung}

Peran perempuan dalam bentuk pekerjaan produktif tak langsung adalah peran domestik sebagai istri dan/atau ibu dalam rumah tangga; yang terdiri dari peran kodrati dan peran sosio-kultural. Peran domestik ini disebut produktif tak langsung karena bersifat intangible artinya tidak dinilai dengan uang, meskipun sebagian dapat disetarakan dengan uang berdasarkan upah yang berlaku jika pekerjaan tersebut dilakukan oleh orang lain, namun ada hal-hal yang tetap tak ternilai dengan uang berapa pun. Meskipun dalam menjalankan peran domestik ini perempuan tidak menghasilkan uang, namun tetap dikatagorikan peran produktif, mengingat hasil yang diperoleh adalah kesejahteraan, kenyamanan, kebahagiaan bahkan kelangsungan hidup keluarga/anggota rumah tangga.Dampak Covid pada peran domestik kegiatan sehari-hari sebagai ibu rumah tangga adalah dampak dari program nasional pencegahan penularan Covid, yaitu: bekerja dari rumah (WFH = work form home), belajar dari rumah $(\mathrm{SFH}=$ School from Home) dan beribadah dari rumah (PFH = pray form home). Dengan berkumpulnya seluruh anggota rumah tangga selama 24 jam di rumah, jelas lbu menjadi lebih sibuk.

Beberapa penyesuaian harus dilakukan. Misalnya, sebelum Covid ada dukungan untuk subtitusi pengasuhan anak selama ibu berkerja di luar rumah. Beberapa informan menyatakan selama ini anak dititipkan ke neneknya, tante nya, atau pembantu di rumah. Sejak Covid, anak diasuh langsung oleh ibu dengan berbagai alasan, yaitu: lebih punya waktu untuk mengasuh anak, peralihan teknologi untuk belajar dari rumah, dan alasan ekonomi. Hal ini merupakan sesuatu yang disyukuri oleh semua informan, meskipun beban pekerjaan dalam peran domestik pengasuhan anak menjadi bertambah. Menarik, bahwa seorang informan merasa kehilangan waktu buat diri sendiri (me time) dengan tidak bekerja di luar rumah. Informan tersebut merupakan disainer dalam sebuah perusahaan swasta, yang memang dalam melakukan pekerjaannya butuh waktu menyendiri untuk fokus berkreasi membuat gambar disain.

“.... Walaupun saya merasa kehilangan 'me time' untuk diri sendiri yang saya dapatkan kalau bekerja di kantor, saya senang setiap hari bisa dekat dan mengasuh anak saya sendiri yang masih balita, jadi saya bisa memantau tumbuh kembangnya dan bisa lihat sendiri pertambahan kata-kata atau gerak/kepintaran barunya..." (pr, 35 th, S2, disainer konsultan swasta, pemilik usaha cake rumahan)

Adanya program belajar dari rumah, membuat ibu harus mengambil alih peran guru yang selama ini membantu para ibu dalam menjalankan peran mendidik anak di sekolah. Meskipun awalnya agak merepotkan karena para ibu harus belajar tentang apa dan bagaimana menjalankan program belajar dari rumah (SFH), namun pada akhirnya para informan cukup menikmatinya. Tampaknya kegiatan SFH ini telah menjadi rutinitas baru sebagai waktu yang berkualitas (quality time) bagi hubungan ibu dan anak. Berbeda dengan aktifitas berberes, bersih-bersih rumah, sebagian informan terutama yang tidak biasa melakukannya merasa kelelahan dan menanggapnya beban berat yang tidak menyenangkan.

"... selama ini ketika masih kerja, ketiga anak ku, dua yang SD dan satu masih balita diasuh oleh nenek nya (ibuku) di kampung... tapi karena ada program belajar on-line, ibuku ga sanggup membimbing belajar di rumah, maklumlah beliau sudah tua tidak ngerti pakai smart-phone... jadi sekarang saya yang ngasuh sendiri di Jakarta. Saya senang bisa kumpul dengan semua anak saya, ... bisa menyuapin si kecil, sore2 ngajarin mereka ngaji, dan membantu pelajaran sekolah secara on-line untuk anakku yang SD... meski setiap hari khawatir apakah besok punya uang tuk belanja buat masakin makanan anak-anak..." (pr, 36 th, SMA, pegawai Salon, usaha jasa pijat/lulur panggilan)

"....selama saya bekerja ada 2 mbak (ART) yang mengasuh anak-anak di rumah dan beberes bersihbersih rumah..., tapi sejak kantor saya tutup, saya terpaksa memberhentikan ART, awal nya satu yaitu yang ngasuh anak-anak, tapi kemudian ART satu lagi juga terpaksa saya lepas...karena kondisi keuangan kami sudah tidak mampu menggaji ART... saya senang mengasuh dan mendidik anak saya sendiri... tapi capek juga kalo mesti berberes, bersih-bersih rumah dan cuci-cuci.." (pr, 48 th, S1, exkabag HRD di perusahaan travel, usaha roti rumahan)

\section{Peran Publik Perempuan: Kegiatan Produktif Langsung}

Peran perempuan dalam bentuk pekerjaan produktif langsung adalah peran publik perempuan sebagai warganegara, anggota masyarakat, dan/atau sumberdaya manusia untuk Pembangunan Indonesia. Peran ini 
disebut peran publik, karena berkaitan dengan kegiatan di luar urusan domestik rumah tangga, dan pada umumnya berada di ranah publik atau di luar rumah. Peran publik ini biasa dibagi 2, yaitu peran ekonomi dan peran sosial. Peran secara social umumnya intangible, artinya tidak menghasilkan uang, tapi tetap merupakan peran produktif karena berkontribusi bagi kesejahteraan masyarakat dan/atau partisipasi dalam pencapaian tujuan-tujuan pembangunan NKRI. Sedangkan peran ekonomi adalah peran perempuan dalam bidang ekonomi yang menghasilkan uang bagi yang bersangkutan, sehingga disebut peran produktif yang tangible. Uang yang dihasilkan perempuan merupakan sarana input untuk kesejahteraan, kenyamanan, kebahagiaan hidup keluarga yang menjadi tujuan akhir yang ingin dicapai rumah tangga.

Semua informan sebelum pandemic Covid-19 adalah ibu yang bekerja, artinya mereka menjalankan peran public yaitu peran ekonomi. Jadi rumah tangga mereka awalnya cukup sejahtera, karena ditunjang oleh 2 pendapatan karena di dalam rumah tangga suami dan istri memiliki pendapatan dan saling menopang untuk memenuhi kebutuhan rumah tangga. Dalam era sekarang, banyak perempuan bekerja sebagai pencari nafkah keluarga bersama suami. Sudah lazim di masyarakat masa kini adanya rumah tangga yang perekonomian nya ditanggung berdua suami-istri, dikenal dengan istilah 'double gardan'. Era ini cocok dengan gambaran Hubeis pada katagori ke-3 (Dwiperan) atau ke-4 (Peran Egaliterian) dalam pengkatagorian peran perempuan di masyarakat dari masa ke masa (Hubeis, 2010). Era Dwiperan memposisikan perempuan dalam kehidupan dua dunia, yaitu menempatkan peran domestik dan publik dalam posisi sama penting. Dukungan moral suami diperlukan sebagai pemicu ketegaran, atau sebaliknya keengganan suami akan memicu keresahan atau bahkan menimbulkan konflik terbuka atau terpendam. Sedangkan dalam katagori era Peran Egaliterian sebagian besar waktu dan perhatian perempuan tersita untuk kegiatan di luar. Dukungan moral dan tingkat kepedulian lelaki sangat hakiki untuk menghindari konflik kepentingan pemilahan dan pendistribusian peranan. Jika tidak, yang terjadi adalah masing-masing akan saling berargumentasi untuk mencari pembenaran yang menumbuhkan ketidaknyamanan suasana kehidupan berkeluarga. Situasi ini berbeda dengan generasi sebelumnya, dimana jika istri bekerja cenderung dianggap "cuma bantu-bantu suami", yang sering menjustifikasi ketimpangan gender dalam system pengupahan dan pajak. Bahkan jika penghasilan istri yang lebih besar dari suami dapat memicu konflik di keluarga, baik secara internal di keluarga batih/inti, maupun secara eksternal di keluarga besar (extended family). Saat bencana pandemic Covid sekarang, kehilangan atau pun pengurangan pendapatan dari salah satu suami atau istri benar-benar menimbulkan goncangan (shock) dalam perekonomian keluarga yang rumah tangganya sebelum pandemi Covid-19 memiliki penghasilan yang berasal dari kedua suami dan istri.

Perempuan yang bekerja sebagai wirausaha, juga harus cermat agar bisa mempertahankan usaha yang dimilikinya. Dalam situasi bencana COVID-19 ini, kemampuan wirausahawan/ti mempertahankan keberlanjutan usahanya sangat penting tidak saja bagi sumber pendapatan keluarganya sendiri, tetapi juga para pekerjanya maupun pemangku kepentingan (stakeholder) lainnya seperti para pemasok (supplier) bahan baku dan juga para konsumennya. Dapat dinyatakan bahwa perempuan memiliki peran yang sangat krusial dalam situasi bencana pandemic COVID-19 ini. Ketika PSBB dan PKMB diberlakukan, banyak usaha yang tutup, rumah tangga informan mengalami pengurangan pendapatan secara signifikan.

Setelah terjadi bencana pandemi Covid, terutama pada masa awal dimana pemerintah memberlakukan PSBB (pembatasan sosial berskala besar), maka banyak pekerja yang dirumahkan dan mengalami pengurangan pendapatan.

“... kami 'anak salon' mendapatkan gaji pokok 700 ribu/bulan, lalu komisi $20 \%$ dari tarif setiap jasa pelayanan... misal tarif jasa creambath rambut berapa, maka kami dapat $20 \%$ nya yang dikumpulkan dan dihitung lalu kami terima bersama gaji pokok pada ahir bulan ...kalau tips dari klien itu sepenuhnya untuk kami .... Saya tiap bulan bisa dapat 3,5 sampai 4 jutaan, selain tiap hari bawa pulang uang tips minimal 50 bisa sampai 200 ribu kalo lagi pas rame... Jadi penghasilan berdua suami cukup tuk biayai 2 rumah tangga, 1) rumah kontrakan di Jakarta membiayai makan-minum, ongkos dan uang sekolah untuk aku, suami, anak sulungku yang SMP dan adik bungsku yang SMA; dan 2) ngirimi ibu ku di kampung tuk biayai ketiga anakku yang diasuh ayah \& ibuku yang sudah tua dan tidak kerja lagi.... Saat Covid, Salon tutup tapi bos tetap kasih gaji pokok 700ribu.... Kemudian dalam era "new normal" kapasitas pekerja salon hanya boleh 50\%... jadi kami masuk bergiliran sehari masuk sehari tidak... Tapi Salon sepi... tidak banyak pelanggan yang datang... sehari paling cuma bisa pegang 1 atau maksimal 3 pelanggan, malah pernah seharian tidak satupun pelanggan yang datang....jadi pendapatan harian dari uang tips sedikit banget, kadang cuma cukup buat makan siang saat kerja, atau kadang ga ada sama sekali... Sedangkan gaji plus 
komisi bulanan cuma dapet sejutaan, paling tinggi 1,2 juta..." (pr, 36 th, SMA, pegawai Salon, usaha jasa pijat/lulur panggilan)

"Saya selalu berdoa supaya dapat orderan ngurut tiap hari...supaya punya uang untuk belanja dapur... Sejak Covid susah dapat order...bahkan awal-awal Covid berminggu-minggu ga ada order sama sekali .....mungkin langganan pada takut kena tular Covid..." (pr, 35 tahun, SMA, urut/pijat on-line, usaha jualan on-line re-seller masker, bros, cantelan masker dan aneka pernik2 kriya lainnya).

\section{Pola Pengeluaran Rumah tangga Selama Covid-19}

Selama bencana pandemi Covid ada pos-pos pengeluaran yang bertambah dan ada yang berkurang. Pos yang bertambah adalah biaya dapur diikuti biaya listrik dan internet/kuota pulsa telepon genggam (HP). Pengeluaran untuk belanja dapur serta makan dan minum juga meningkat, karena ada tambahan pengeluaran untuk vitamin dan makanan extra tuk meningkatan daya tahan tubuh seluruh anggota keluarga. Selain itu, pos belanja dapur juga meningkat karena menggantikan makan siang dan jajan yang biasanya dikeluarkan saat anggota keluarga beraktifitas di kantor atau di sekolah. Pos lain yang juga bertambah adalah belanja bahan dan alat untuk perlindungan diri dari Covid seperti masker, hand sanitizer, desinfektan, dll. Sedangkan pos lain berkurang, adalah belanja pakaian, tas, sepatu, kosmetik, rekreasi, jalan-jalan, jajan/makan di luar, dsb.

"....saya ga mikir mau beli-beli yang lain... yang penting bisa masakin makanan buat anak-anak...." (pr, 35 tahun, SMA, tukang urut/pijat on-line, usaha jualan on-line re-seller masker, bros, cantelan masker dan aneka pernik2 kriya lainnya)

"... banyak penghematan...karena kita tidak bisa keluar rumah... jadi tidak ke mall, tidak makan di restoran, tidak nonton bioskop, atau pergi rekreasi..." (pr, 35 th, S2, disainer konsultan swasta, pemilik usaha cake rumahan).

Strategi untuk bertahan dalam situasi berkurangnya pendapatan adalah melakukan penghematan, mengatur belanja dengan lebih bijak dan cermat, menetapkan prioritas pengeluaran rumah tangga, dll.

“... harus cermat mengelola uang... karena sekarang sumber pendapatan cuma dari satu orang... Alhamdulillah suamiku masih dibayar penuh gaji nya biarpun WFH... tapi cukup terasa (dampaknya terhadap pengurangan keuangan rumah tangga, pen) setelah saya tidak punya penghasilan.." (pr, 48 th, S1, ex-kabag HRD di perusahaan travel, usaha roti rumahan)

Strategi lain dalam pengelolaan pendapatan yang berkurang akibat bencana pandemic Covid adalah adanya upaya-upaya untuk mendapatkan penghasilan tambahan. Hal ini dimungkinkan karena semasa pandemi Covid-19, para informan memiliki waktu lebih banyak untuk menjalankan bisnis dari rumah. Baik bisnis yang sudah ada sebelumnya, maupun bisnis baru. Bisnis yang sudah ada sebelumnya, antara lain adalah toko online, jual beli emas, dan jual kue \& roti buatan sendiri.

“... saya sejak beberapa tahun yang lalu ikut bisnis jual-beli emas via on-line. Selama Covid ini cukup banyak transaksi nya....Banyak orang melepas emas nya.... mungkin karena butuh untuk menutupi biaya rumah tangga karena pendapatan yang berkurang atau hilang sama sekali .... Tapi ada juga yang membeli emas dari saya.... Mungkin mereka dapat dana lebih dari penghematan pengeluaran karena tidak bisa rekreasi atau traveling,... trus duitnya diinvestasikan dengan beli emas.... Abis, dalam situasi tak menentu seperti sekarang, perekonomian negara terpuruk entah sampai kapan Covid ini berlalu, memang daripada menyimpan uang lebih baik menyimpan emas...lebih terjamin stabil nilainya" (pr, 44 th, S2, dosen swasta, jual beli emas secara on-line)

"....saya sebelumnya sudah punya bisnis jualan kue dan roti buatan sendiri via on-line...tapi agak terbengkalai sewaktu kerja, kini karena di rumah aja jadi punya waktu tuk mengembangkannya lagi..." (pr, 35 th, S2, disainer konsultan swasta, pemilik usaha cake rumahan).

Sebagian informan lain menyatakan upaya yang dilakukan untuk mencari tambahan penghasilan adalah dengan membuka bisnis baru yang mampu dilakukan. Usaha baru ini adalah memanfaatkan keahlian yang memang sudah dimiliki serta waktu yang lebih banyak di rumah. Misalnya: Pegawai salon menbuka usaha pijat lulur yang melayani panggilan ke rumah pelanggan. Mitra/pekerja perusahaan on-line jasa urut/pijat, yang terbiasa menggunakan aplikasi on-line membuka usaha re-seller produk2 yang laku saat Covid secara on-line. 


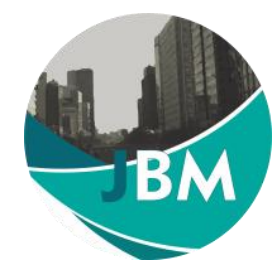

".....karena saya WFH sekarang, jadi ada waktu mengembangkan bisnis masakan jadi bersama ibu saya yang tinggal bersama saya di rumah, ibu saya yang masak, saya yang packing dan memasarkannya via WA... banyak ibu-ibu di komplekku dan teman-teman kenalan keluarga yang tinggalnya tidak terlalu jauh, ga sempat masak, tapi ga bisa beli makanan di luar rumah, jadi mereka senang bisa beli di kami..dianter/dikirim via gojek atau grab mereka yang bayar ongkos kirim nya" (pr, 40 th, S1, karyawan swasta, usaha masakan jadi).

Namun, tidak semua upaya ini berhasil. Seorang informan ex-HRD perusahaan travel sempat ikut kursus belajar membuat roti kemudian membuka usaha jualan roti meskipun ahirnya tutup.

".... Saat awal terpaksa di PHK karena kantorku tutup, saya bingung mau ngapain di rumah... belum lagi mikir bagaimana mencari uang tuk biaya sekolah anakku, sedangkan penghasilan suami cuma cukup buat kebutuhan hidup sehari-hari, itupun pas-pasan... Saya lalu kursus buat roti, sampai berhasil bikin roti yang enak menurut keluarga, saudara dan teman-teman. Kemudian saya memutuskan buka usaha jualan roti bikinan sendiri via med-sos. Tapi hasilnya tak seberapa...., sehari hanya 6 sampai sepuluh roti yang terjual... Akhirnya, bulan lalu saya memutuskan untuk berhenti saja..." (pr, 48 th, S1, ex-kabag HRD di perusahaan travel, usaha roti rumahan)

Menurut hasil penelitian Rosita, (2020) industri (termasuk UMKM/industri rumah tangga) yang mampu bertahan di tengah pandemi Covid-19 adalah industri yang terkait dengan pemenuhan kebutuhan dasar, yang meliputi listrik, air bersih, pertanian, peternakan, perkebunan, perikanan, otomotif dan perbankan. Pemanfaatan penjualan melalui pemasaran digital juga menjadi prasyarat bagi industri ritel untuk mampu bertahan di tengah situasi pandemic Covid-19 yang membatasi mobilitas dan pertemuan tatap muka langsung antar warga masyarakat.

\section{Peran Publik Berupa Aktifitas Social}

Salah satu informan menyatakan bahwa dia aktif dalam Gerakan "Bunda Peduli" yang dalam masa sulit akibat pandemi Covid ini mengumpulkan dana untuk menyediakan makanan bagi anggota masyarakat yang membutuhkan.

".....saya adalah anggota 'Bunda Peduli'...,kami membagi-bagikan nasi bungkus ke komunitas miskin..." (pr, 44 th, S2, dosen swasta, jual beli emas on-line)

Cukup menyentuh bahwa ada informan yang tetap berusaha menyantuni orangtua nya yang sudah lansia meskipun sedang dalam kesulitan keuangan rumah tangga selama bencana pandemi Covid-19 ini terjadi.

"... saya dan suami sepakat untuk tetap mengirim bapak-ibu dari gaji suami... meskipun jumlahnya berkurang separuh dari sebelumnya, tapi kan anak-anak ku sudah tidak ikut ibu ku lagi di kampung, sudah bersamaku di Jakarta... itu saja hampir seluruh gaji suami (Satpam di salah satu kantor perusahaan Telekomunikasi yang tidak terdampak Covid, pen) dikasihkan ke ibu... abis kasian, sudah tua dan sakitsakitan, tidak bisa kerja tidak punya pengahsilan maupun tabungan...Cuma kami satu-satunya anak yang membiayai hidup mereka... saudara-saudara saya yang lain ga ada yang ngirim selama ini... kalau saya sih sesulit apapun hidup di Jakarta tetep nyisihin duit buat ibu-bapak... Suami ku bilang supaya rezeki kita barokah, tetap sehat ga sakit, Insyaallah dicukupkan rezeki dari usaha saya buat makan kami sekeluarga ...buat sekolah anak-anak "(pr, 36 th, SMA, pegawai Salon, usaha jasa pijat/lulur panggilan)

\section{Kesimpulan}

Pengetahuan, sikap dan perilaku perempuan yang menjadi informan penelitian ini tentang bencana pandemi Covid sudah cukup baik. Tampak bahwa pada saat penelitian ini dilakukan sosialisasi massif tentang pencegahan Covid sudah diterima dan dilaksanakan oleh masyarakat, khususnya oleh para perempuan yang menjadi informan penelitian ini.

Dampak covid pada peran domestik perempuan tampak pada penyesuaian aktifitas sehari-hari di rumah akibat seluruh anggota keluarga berkumpul 24 jam di rumah akibat aktifitas bekerja, belajar dan beribadah dari rumah (WFH, SFH dan PFH). Peningkatan aktifitas domestik dan juga mrupakan tambahan beban terutama dalam hal penyediaan makanan bergizi dan multi vitamin serta ramuan makanan/minuman yang diyakini dapat meningkatkan imunitas tubuh guna melawan Covid. Peran yang juga menuntut lebih banyak aktifitas dan 
curahan waktu adalah peran dalam mendidik anak, khususnya bagi perempuan yang memiliki anak usia sekolah di SD. Namun pada akhirnya, aktifitas mendampingi anak belajar on-line diakui menjadi waktu yang berkualitas untuk mempererat hubungan orangtua dan anak.

Peran publik yang dilakukan adalah peran ekonomi untuk menunjang perekonomian keluarga. Dalam situasi pandemic Covid ini, perempuan kesulitan dalam aktifitas bekerja, karena situasi perekonomian global yang menyebabkan banyak kantor yang tutup serta pembatasan aktifitas masyarakat untuk tidak keluar rumah. Situasi yang tak menentu dan belum pasti kapan akan berakhir, disikapi oleh rumah tangga konsumen dengan penghematan yang dilakukan keluarga, dan menyimpan cadangan dana darurat yang dimiliki. Hal ini menyebabkan para pekerja lepas maupun pemilik usaha UMKM kehilangan pelanggannya. Dampaknya adalah penurunan pendapatan rumah tangga khususnya bagi pekerja sektor tertentu dan pemilik UMKM.

Perubahan pola pengeluaran rumah tangga untuk menyesuaikan dengan pendapatan yang berkurang adalah merupakan aktifitas pelaksanaan peran perempuan sebagai pengelola keuangan rumah tangga. Penyesuaian yang dilakukan adalah berhemat, cermat dan bijak dalam menentukan prioritas pengeluaran untuk memenuhi kebutuhan keluarga. Pos-pos pengeluaran yang bertambah adalah belanja dapur termasuk penyediaan vitamin dan makanan/minuman yang dapat meningkatkan imunitas tubuh guna melawan Covid, pembelian bahan dan sarana tuk melindungi diri dari Covid (masker, hand sanitizer, desinfektan, dll. Pos lain yang juga meningkat adalah biaya listrik dan pulsa telepon yangdibutuhkan anggota keluarga agar bisa bekerja, belajar bahkan beribadah dan bersosialisasi dari rumah saja. Sedangkan pos-pos lain berkurang, yaitu: pos pembelian pakaian/sepatu.tas, kosmetik, dan rekreasi.

Saran bagi penelitian selanjutnya adalah perlu dilakukan survey pendekatan kualitatif dengan membuat pertanyaan kuantitatif yang dapat mengukur lebih jauh tentang: a) besaran rata-rata penurunan pendapatan, serta besaran turun-naiknya pos-pos pengeluaran rumah tangga akibat pandemic Covid-19 ini secara lebih detil; b) informasi yang lebih luas tentang persepsi, pemahaman dan praktek dalam penanggulangan bencana pandemic Covid-19 yang telah dan bisa dilakukan oleh rumah tangga konsumen; c) hal-hal yang telah dan bisa dilakukan untuk pemulihan ekonomi keluarga melalui upaya bertahan dan pemulihan UMKM berbasis usaha rumahan atau industri rumah tangga. Dengan denikian akan diperoleh data dan informasi yang dapat menjadi masukan bagi penyusunan strategi percepatan pemulihan ekonomi nasional melalui peningkatan peran pengusaha perempuan yang memiliki UMKM berbasis rumah tangga dalam penanggulangan bencana pandemic Covid-19.

\section{Daftar Pustaka}

BPS -a. (2021). Hasil Sensus Penduduk 2020. Badan Pusat Statistik. Jan 21. https://www.bps.go.id/website/images/Hasil-SP2020-ind.jpg.

BPS -b. (2021). Hasil Sensus Pnduduk Indonesia 2020. Biro Pusat Statistik. Jan 21. https://www.bps.go.id/website/materi_ind/materiBrsInd-20210121151046.pdf.

BPS -c. (2021). Pertumbuhan Ekonomi Produk Domestik Bruto. Biro Pusat Statistik. Februari 5. https://www.bps.go.id/website/materi_ind/materiBrsInd-20210205095341.pdf.

BPS -e. (2021). Profil Kemiskinan di Indonesia. Hasil Susenas September 2020. Februari 15. https://www.bps.go.id/website/materi_ind/materiBrsInd-20210215114827.pdf.

BPS-d. (2020). Keadaan Tenaga Kerja Indonesia - Agustus 2020. Hasil Survei Tenaga Kerja Nasional (Sakernas) Agustus 2020. November 5. https://www.bps.go.id/website /materi_ind/materiBrsInd20201105120056.pdf.

GHRF Commission (Commission on a Global Health Risk Framework for the Future). (2016). "Global Health Risk Framework-The Neglected Dimension of Global Security: A Framework to Counter Infectious Disease Crises 16 January 2016. Washington, DC: National Academy of Medicine. doi:10.17226/21891.

Hastuti. (2016). "Perran Perempuan dalam Menghadapi Bencana di Indonesia." Geonedia 14 (2): 1.

Hubeis, Aida Vitalaya. (2010). Pemberdayaan Perempuan dari Masa ke Masa. Bogor: IPB Press.

International Strategy for Disaster Reduction (ISDR). (2009). 2009 UNISDR Terminology on Disaster Risk Reduction. Geneva: United Nations International Strategy for Disaster Reduction (UNISDR). https://www.unisdr.org/files/7817_UNISDRTerminology English.pdf. 


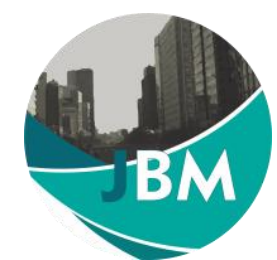

Kementerian Keuangan Republik Indonesia. (2020). "Kerangkan Ekonomi Makro dan Pokok-pokok Kebijakan Fiskal Tahun 2021." https://fiskal.kemenkeu.go.id/data/document/kem/2021/files/kem_ppkf_2021.pdf. Mei 10. https://fiskal.kemenkeu.go.id/data/document/kem/2021/files/kem_ppkf_2021.pdf.

Nugroho, Sutopo Purwo. (2016). Evaluasi Penanggulangan Bencana 2015 dan Prediksi Bencana 2016. . Jakarta: BNPB (Badan Nasional Penanggulangan Bencana).

Nurjanah. (2012). Manajemen Bencana. Bandung: Alfabeta.

Presiden Republik Indonesia. (2007). "UU No. 24 tahun 2007 tentang Penanggulangan Bencana." LEMBARAN NEGARA REPUBLIK INDONESIA TAHUN 2007 NOMOR 66. Jakarta, DKl: Kementrian Hukum dan Hak Asasi Manusia, April 26. https://bnpb.go.id/ppid/file/UU_24_2007.pdf.

Rahman, Haliza Abdul. (2018). "Community Based Approach Towards Disaster Management in Malaysia." Research Gate Open Journal 1-14. https://www.researchgate.net /publication/327416226_Community_Based_Approach_Towards_Disaster_Management_in_Malaysia/link/ 5b8e0b70299bf114b7f05c6b/download.

Rosenwald, Michael S. (2020). "History's deadliest pandemics, from ancient Rome to modern America". The Washington Post. Archived, Apr 7: 1.

Rosita, Rahmi . (2020). "Pengaruh Pandemi Covid-19 Terhadap UMKM Di Indonesia." Jurnal Lentera Bisnis 9 (2): 109-120. doi:DOI : 10.34127/jrlab.v9i2.380.

Roychoudhury, Shubhadeep, Anandan Das, Pallav Sengupta, Sulagna Dutta, Shatabhisha Roychoudhury; Arun Paul Choudhury, Fuzayel A. B. Ahmed, Saumendra Bhattacharjee, and Petr Slama. 2020. "Viral Pandemics of the Last Four Decades: Pathophysiology, Health Impacts and Perspectives". International Journal of Environmental Research and Public Health 17 (24): 9311. doi:10.3390/ijerph17249411.

Sebayang, Rehia. (2020). " WHO Nyatakan Wabah COVID-19 jadi Pandemi, Apa Maksud-nya?." CNBC Indonesia. News. March 12. https://www.cnbcindonesia.com /news/20200312075307-4-144247.

Stawicki, Stanislawp, and et al. (2020). "The 2019-2020 novel coronavirus (Severe acute respiratory syndrome coronavirus 2) pandemic: A joint american college of academic international medicine-world academic council of emergency medicine multidisciplinary COVID-19 working group consensus paper." Journal of Global Infectious Diseases 12 (2): 47-93. doi:10.4103/jgid.jgid_86_20.

WHO/EHA. (2002). Disaster \& Emergency Defenition: training package. Adiss Ababa: Pan African Training Centre - World Health Organization. https://apps.who.int/disasters/repo/7656.pdf.

Worldometer. (2021). Reported Cases and Deaths by Country, Territory, or Conveyance. Chicago, Illinois 60601: American Library Association (ALA). https://www.worldometers.info/coronavirus/. 